\title{
DRAMATIZATION STRATEGY AND JUNIOR HIGH SCHOOL STUDENTS' READING MOTIVATION
}

\author{
Vismaia Sabariah Damaianti \\ Indonesia University Of Education \\ Jalan Dr. Setiabudhi No.229 Bandung, Indonesia \\ Corresponding Author: vismaia@upi.edu
}

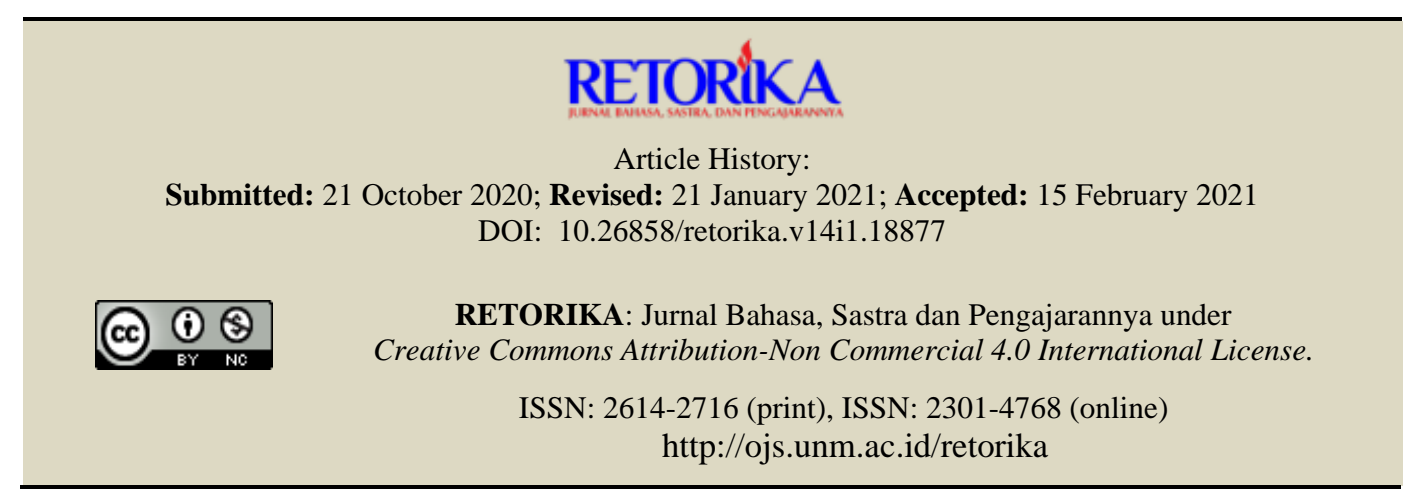

\begin{abstract}
This study is motivated by many expert opinions which state that the students' reading motivation in Indonesia still needs to be increased. The researcher tries to answer the problem by trying out a Dramatization Strategy in reading learning with the aim of increasing reading motivation. This strategy is carried out by developing students' cognitive and metacognitive abilities. The experimental method with a factorial design is chosen to determine the effectiveness of the Dramatization Strategy, either for readers with high- or low-level reading comprehension. The data sources of this study are 101 students of Madrasah Tsanawiyah in Bandung Regency and Bandung City. The results of the study show that the Dramatization Strategy is effective in increasing reading motivation, especially for improving reading skills and for social interaction. The implication of the study is the need for the application of the dramatization strategy by adjusting the teachers' insights and abilities in identifying students' reading motivation.
\end{abstract}

Keywords: reading skills, reading motivation, dramatization strategy

Reading skills are a world opener and a new opportunity for individuals who have them. With reading skills, a person can acquire a lot of new knowledge and be able to carry out activities in modern life (Hermida, 2009). Various studies have proven the importance of having the reading skills, from achieving academic success, to achieving professional success. Students who read frequently are students who are successful in their academic (Gottfried, Schlackman, Gottfried, \& Boutin-Martinez, 2015; Mol \& Bus, 2011; Taylor, 2013). High-level reading comprehension skills, apart from being important for academic and professional achievement, are also important for individual involvement in society and social life (Snow, 2002). It means that there is a serious risk that many individuals can not develop their reading skills. They cannot use their reading skills they need as members of contemporary society and they do not get benefit from 21 st century information.

Reading skills, especially for middle school students, need to be mastered. However, the reading skills required at the intermediate 
level are very different from those required in the elementary level. Students are no longer taught how to read, but they learn to read to gain skills as a tool to master and to understand various fields of science (Dieker \& Little, 2005). Even teaching children is not enough, teachers must teach them to want to read. This means that teachers must create children with high reading motivation. A research related to reading motivation proves that motivation is a component in the psychological domain that can affect reading comprehension (Cartwright et al., 2015).

Motivated readers tend to engage in reading material and persist to continue to understand the text even when they face challenges (Cain, \& Barnes, 2017; Schiefele, 2011). More indepth research shows that motivated readers tend to choose reading materials that are more challenging, persevere when reading difficult texts, process reading information cognitively more deeply, and understand them better (Anderson et al., 1988; Schiefele, 2011). On the other hand, in a research report by Morgan \& Fuchs (2007) on the relationship between reading motivation and reading achievement, it shows that low reading motivation will have consequences on the acquisition of limited reading skills and become the cause of reading failure later in life.

Moreover, the right strategy is needed in an effort to teach children to read so that they are willing and motivated to read. An instructional approach that only focuses on developing reading skills, without considering its effect on students' reading motivation, does not add to the effect on their overall reading achievement (Quirk, Schwanenflugel, \& Webb, 2009).

This study selects the dramatization strategy as a powerful way to learn reading in order to obtain good reading comprehension, adequate reading motivation, and fun learning atmosphere. Dramatization has the potential to make the learning experience enjoyable and even impressive for students (Boudreault, 2010). This statement is one of the reasons for this study to choose the dramatization strategy in reading learning to increase reading motivation.

Recently, only a few studies have examined reading motivation in school settings and in recreational contexts (De Naeghel et al., 2012; McGeown et al., 2016). Students will feel more independent when reading in a recreational context, so that reading motivation is higher (Locher, Becker, Pfost, 2019).

In addition, some experts state that the dramatization strategy in learning reading provide opportunities to get students willing to read as they start to enjoy reading activities. This strategy provides students with background knowledge and reading skills. Most importantly, students have more positive attitudes toward learning (Smith \& Herring, 1993) and reading motivation (McMaster, 1998).

\section{METHOD}

This study uses experimental method since the researcher wants to see the effectiveness of the dramatization strategy in increasing reading motivation. The experimental design refers to a factorial design pattern (Fraenkel, Wallen, \& Hyun, 2012). Through this design, the researcher can pay attention to the possibility of the moderator variable, namely reading comprehension that affects the treatment (the dramatization strategy) to the dependent variable (reading motivation).

In the experimental design with factorial design, four groups are formed, namely two experimental groups and two control groups. Both the experimental group and the control group each has one group with high-level reading comprehension and one group with a low-level reading comprehension. The form of factorial experimental design can be seen in table 1 .

The data are in the form of students' reading motivation characteristics. The research subjects are 300 junior high school students/ MTs in Bandung Regency. As there are too many subjects, random sampling is carried out for this experimental purpose. Furthermore, the samples are grouped based on the level of reading comprehension. This grouping is done by providing a reading comprehension test to all samples. The number of samples for each group is shown in the following figure. 
Table 1. Research Design

\begin{tabular}{cccccc}
\hline $\begin{array}{c}\text { Random } \\
\text { Samples }\end{array}$ & Pretest & $\begin{array}{c}\text { Dramatization } \\
\text { Strategy Treatment }\end{array}$ & Moderator Variable & Posttest \\
\hline & & & $\begin{array}{c}\text { High-level } \\
\text { reading } \\
\text { comprehensio } \\
\text { Low-level } \\
\text { reading } \\
\text { comprehensi } \\
\text { on }\end{array}$ & \\
\hline R1 & O1 & X & Y1 & & O2 \\
\hline R2 & O3 & & Y1 & O4 \\
\hline R3 & O5 & $\mathrm{X}$ & & Y2 & O6 \\
\hline R4 & O7 & & & O8 \\
\hline
\end{tabular}

The collected data are processed and analyzed using the statistical technique of the two-mean difference test. This technique is used to determine whether there is a difference in the level of reading motivation in the experimental groups and the control groups, either in high- or low-level reading comprehension groups. The data processing in this study uses IBM SPSS Statistics 24.

Table 2. Research Subjects

\begin{tabular}{ccl}
\hline No. & $\begin{array}{c}\text { Number } \\
\text { of } \\
\text { Subjects }\end{array}$ & \multicolumn{2}{c}{ Group } \\
\hline 1. & 32 & $\begin{array}{l}\text { An experimental group with } \\
\text { high-level reading comprehen- } \\
\text { sion }\end{array}$ \\
\hline 2. & 32 & $\begin{array}{l}\text { An experimental group with } \\
\text { low-level reading comprehen- } \\
\text { sion }\end{array}$ \\
\hline 3. & 18 & $\begin{array}{l}\text { A control group with high-level } \\
\text { reading comprehension }\end{array}$ \\
\hline 4. & 19 & $\begin{array}{l}\text { A control group with low-level } \\
\text { reading comprehension }\end{array}$ \\
\hline
\end{tabular}

\section{FINDINGS AND DISCUSSION}

\section{Findings}

To test the research hypothesis, the required data is reading motivation profile data for each testing group as in the following description.

Reading Motivation Profile of Students with High- and Low-level Reading Comprehension Before and After Performing the Dramatization Strategy

The students' reading motivation profile will be described below. It consists of a group of students having high-level reading comprehen- sion and a group of students having low-level reading comprehension, before and after carrying out the dramatization strategy. The student's reading motivation profile consists of five aspects, namely willing to read in order to: (1) gain understanding of the material being read; (2) get satisfaction from the material read (3) get the ability to interact socially; (4) overcome difficulties in reading; (5) improve reading skills. The reading motivation profile can be seen in table 3 below.

Table 3. Reading Motivation Profile of Students Having High- and Low-level Reading Comprehension

\begin{tabular}{ccccc}
\hline $\begin{array}{c}\text { Aspects of } \\
\text { Reading } \\
\text { Motivation }\end{array}$ & $\begin{array}{c}\text { Mean } \\
\text { Pre }\end{array}$ & $\begin{array}{c}\text { Mean } \\
\text { Post }\end{array}$ & $\begin{array}{c}\text { Standard } \\
\text { Deviation } \\
\text { E } \\
\text { Pre }\end{array}$ & $\begin{array}{c}\text { Standard } \\
\text { Deviation } \\
\text { E } \\
\text { Post }\end{array}$ \\
\hline $\begin{array}{c}\text { Gaining } \\
\text { understanding }\end{array}$ & 17,41 & 14,97 & 3,52 & 2,44 \\
\hline $\begin{array}{c}\text { Getting } \\
\text { Satisfaction }\end{array}$ & 14,84 & 13,11 & 2,80 & 2,53 \\
\hline $\begin{array}{c}\text { Interacting } \\
\text { Socially }\end{array}$ & 19,42 & 21,00 & 3,73 & 2,93 \\
\hline $\begin{array}{c}\text { Overcoming } \\
\text { difficulties }\end{array}$ & 16,98 & 17,20 & 3,77 & 3,46 \\
\hline Improving skills & 21,34 & 23,77 & 3,42 & 2,81 \\
\hline
\end{tabular}

From table 3, it can be concluded that after carrying out the dramatization strategy, students have high reading motivation to gain social interaction skills and to improve their reading skills. It is obtained from the calculation of the mean of the two aspects of reading motivation, namely 21.00 and 23.77. The mean of the two aspects of motivation is higher than the ideal mean score of each aspect of reading motivation, which is 18.00 .

As students have done the Dramatization Strategy, they have relatively the same high reading motivation in two aspects. The two aspects are reading motivation to gain social interaction skills and to improve reading skills. 
The similarity of the two reading motivation is shown by the small coefficient of variation, namely $13.95 \%$ and $11.82 \%$.

Furthermore, after carrying out the dramatization strategy, students have low reading motivation in three types of reading motivation aspects, namely: (1) reading motivation to gain understanding of the material being read, (2) reading motivation to get satisfaction from the material being read, and (3) reading motivation to overcome reading difficulties. It is obtained from the calculation of the mean score of the three aspects of reading motivation, namely 14.97 ; 13.11; and 17,20. The mean score of the three aspects of reading motivation is below the ideal mean score of each aspect of reading motivation, which is 18.00 .

After the students perform the dramatization strategy, they have the same low reading motivation, namely (1) reading motivation to gain understanding, (2) reading motivation to gain satisfaction, and (3) reading motivation to be able to overcome reading difficulties. The similarity of the three aspects of reading motivation is indicated by the small coefficient of variation of the three aspects of reading motivation, namely $16.29 \% ; 19.29 \%$; $20.11 \%$.

\section{Reading Motivation Profile of Students with High-Level Reading Comprehension Before and After Performing the Dramatization Stra- tegy}

The student's reading motivation profile which will be described below consists of groups of students who have high-level reading comprehension before and after carrying out the dramatization strategy. The student's reading motivation profile consists of five aspects, namely willing to read in order to: (1) gain understanding of the material being read; (2) get satisfaction from the material read (3) get the ability to interact socially; (4) overcome difficul-ties in reading; (5) improve reading skills. The reading motivation profile can be seen in table 4 below.

Table 4 can be interpreted that after carrying out the dramatization strategy, students with high-level reading comprehension have high reading motivation to interact socially and to improve their reading skills. It is indicated by the mean scores of the two aspects of reading motivation, namely 20.85 and 24.72 . The mean score of reading motivation for both aspects is higher than the ideal mean score for each aspect of reading motivation, which is 18.00 .

Table 4. Reading Motivation Profile of Students Having High-level Reading Comprehension

\begin{tabular}{lcccc}
\hline $\begin{array}{l}\text { Aspects } \\
\text { Reading } \\
\text { Motivation }\end{array}$ & $\begin{array}{c}\text { ofean } \\
\text { Pre }\end{array}$ & $\begin{array}{c}\text { Mean } \\
\text { E } \\
\text { Post }\end{array}$ & $\begin{array}{c}\text { Standard } \\
\text { Deviation } \\
\text { E } \\
\text { Pre }\end{array}$ & $\begin{array}{c}\text { Standard } \\
\text { Jeviation } \\
\text { Post }\end{array}$ \\
\hline $\begin{array}{l}\text { Gaining } \\
\text { understanding }\end{array}$ & 17,53 & 14,53 & 3,66 & 2,03 \\
\hline $\begin{array}{l}\text { Getting } \\
\text { Satisfaction }\end{array}$ & 14,59 & 12,69 & 2,20 & 2,20 \\
\hline $\begin{array}{l}\text { Interacting } \\
\text { Socially }\end{array}$ & 19,09 & 20,85 & 3,80 & 3,40 \\
\hline $\begin{array}{l}\text { Overcoming } \\
\text { difficulties }\end{array}$ & 16,87 & 17,22 & 4,05 & 3,64 \\
\hline $\begin{array}{l}\text { Improving } \\
\text { skills }\end{array}$ & 21,90 & 24,72 & 3,74 & 3,00 \\
\hline
\end{tabular}

After performing the dramatization strategy, students having high-level reading comprehension have relatively high reading motivation in two aspects. These two aspects are the motivation to read for social interaction and to improve reading skills. It can be explained by the small coefficient of variation of the two aspects of motivation, namely $\mathrm{r} 16.30 \%$ and $12.13 \%$.

It also appears that after students with highlevel reading comprehension perform the dramatization strategy, they have low reading motivation on three aspects of reading motivation. The three aspects are (1) reading motivation to gain understanding of the material being read, (2) reading motivation to get satisfaction from the material being read, and (3) reading motivation to overcome reading difficulties. It is indicated by the mean score of reading motivation for the three aspects of reading motivation, namely 14.53 12.69; and 17.22. The three mean scores of reading motivation are below the ideal mean score of each aspect of reading motivation, which is 18.00

In addition, after doing the strategy, students with high-level reading comprehension, have the same low reading motivation in the three aspects of reading motivation. The three aspects are (1) reading motivation to gain understanding of the material being read, (2) reading motivation to get satisfaction from the material being read, and (3) reading motivation to overcome difficulties in reading. This information can be shown by the small coefficient of variation of the three 
aspects of reading motivation, namely $13.97 \%$; $17.33 \%$; and $21,13 \%$.

\section{Reading Motivation Profile of Students with Low-Level Reading Comprehension Before and After Performing the Dramatization Strategy}

In this section, the reading motivation profile that will be described is the profile of the group of students who have low-level reading comprehension before and after carrying out the dramatization strategy. The student's reading motivation profile consists of five aspects, namely the desire to read in order to: (1) gain understanding of the material being read; (2) get satisfaction from the material read (3) get the ability to interact socially; (4) overcome difficulties in reading; (5) improve reading skills. The reading motivation profile can be seen in table 5 below.

Table 5. Reading Motivation Profile of Students Having Low-level Reading Comprehension

\begin{tabular}{lcccc}
\hline $\begin{array}{l}\text { Aspects of } \\
\text { Reading } \\
\text { Motivation }\end{array}$ & $\begin{array}{c}\text { Mean } \\
\text { Pre }\end{array}$ & $\begin{array}{c}\text { Mean } \\
\text { E } \\
\text { Post }\end{array}$ & $\begin{array}{c}\text { Standard } \\
\text { Deviation } \\
\text { E } \\
\text { Pre }\end{array}$ & $\begin{array}{c}\text { Standard } \\
\text { Deviation } \\
\text { E } \\
\text { Post }\end{array}$ \\
\hline $\begin{array}{l}\text { Gaining } \\
\text { understanding }\end{array}$ & 17,28 & 15,41 & 3,41 & 2,75 \\
\hline $\begin{array}{l}\text { Gaining } \\
\text { understanding }\end{array}$ & 15,09 & 13,53 & 3,32 & 2,79 \\
\hline $\begin{array}{l}\text { Interacting } \\
\text { Socially }\end{array}$ & 19,75 & 21,10 & 3,68 & 2,33 \\
\hline $\begin{array}{l}\text { Overcoming } \\
\text { difficulties }\end{array}$ & 17,09 & 17,16 & 3,54 & 3,34 \\
\hline $\begin{array}{l}\text { Improving } \\
\text { skills }\end{array}$ & 20,78 & 22,81 & 3,03 & 2,24 \\
\hline
\end{tabular}

From table 5, after students carry out the strategy, students who have low-level reading comprehension, have high reading motivation to interact socially and to improve their reading skills. It is explained by the mean scores of the two aspects of reading motivation, namely 21.10 and 22.81 .

The mean score of the two aspects of motivation is higher than the ideal mean score of each aspect of reading motivation, which is 18.00 . After carrying out the dramatization strategy, students with low-level reading skills have the same high reading motivation in the two aspects of reading motivation. The two aspects are reading motivation to gain social interaction skills and to improve reading skills. The similarity of the two reading motivation is indicated by the small coefficient of variation, namely $11.04 \%$ and $9.82 \%$.
Moreover, after carrying out the dramatization strategy, students with low-level reading comprehension, also have low reading motivation in three aspects of reading motivation. The three aspects of reading motivation are: (1) reading motivation to gain understanding of the material being read, (2) reading motivation to get satisfaction from the material being read, and (3) reading motivation to overcome reading difficulties. It is indicated by the mean score of reading motivation for the three aspects of reading motivation, namely $15.41 ; 13.53$; and 17.16. The mean score of the three aspects of reading motivation is below the ideal mean score of each aspect, which is 18.00 .

Besides, after implementing the strategy, students who have low-level reading comprehension have relatively low reading motivation in the three aspects of reading motivation. The three aspects of reading motivation are (1) reading motivation to gain understanding of the material being read, (2) reading motivation to get satisfaction from the material being read, and (3) reading motivation to be able to overcome reading difficulties. It can be obtained from the small coefficient of variation of the three aspects of reading motivation, $17.84 \%$; $20.62 \%$; and $19.46 \%$.

Further, the statistical test used to test the hypothesis is the t-test statistical technique, which is calculated using the IBM SPSS program. The test criterion is to accept Ho if $\mathrm{t}$-count $<\mathrm{t}$-table and to reject Ho for other $t$ values. The following is a table of the results of the calculation of the hypothesis test.

Table 7. Hypothesis Test Results

\begin{tabular}{|l|l|l|l|l|}
\hline No. & Hypothesis & $\mathrm{t}$-count & $\mathrm{t}$-table & Note \\
\hline 1. & Major 1 & 3,12 & 2,00 & $\begin{array}{l}\text { Ho } \\
\text { rejected }\end{array}$ \\
\hline 2. & Minor 1 & 3,33 & 2,00 & $\begin{array}{l}\text { Ho } \\
\text { rejected }\end{array}$ \\
\hline 3. & Minor 2 & 4,72 & 2,00 & $\begin{array}{l}\text { Ho } \\
\text { rejected }\end{array}$ \\
\hline 4. & Major 2 & 7,67 & 2,11 & $\begin{array}{l}\text { Ho } \\
\text { rejected }\end{array}$ \\
\hline 5. & Minor 3 & 7,91 & 2,11 & $\begin{array}{l}\text { Ho } \\
\text { rejected }\end{array}$ \\
\hline 6. & Minor 4 & 6,04 & 2,11 & $\begin{array}{l}\text { Ho } \\
\text { rejected }\end{array}$ \\
\hline
\end{tabular}

\section{Discussion}

The findings about the students' reading motivation profile are resulted from the research 
subjects in the experimental group. It turns out that the dramatization strategy can increase reading motivation, both for students who have high- and low-level reading comprehension. It is indicated by the significant increase in reading motivation scores to students who have high-level reading comprehension. The score for the motivation to want to read to improve reading skills is $12.88 \%$. A significant increase in reading motivation is also shown for students who have lowlevel reading comprehension. The score is $9.82 \%$ for the motivation to want to read to improve reading skills.

The Motivation to improve reading skills is needed to achieve high reading achievement. Without proper reading skills, excellence in secondary schools may not become a reality for children. Many other researchers prove that students who have high reading motivation will have a high reading orientation to increase their knowledge and conceptual understanding of what they read so that they obtain high-level reading skills (Skaalvik, 1997). Reading motivation is important for influencing reading achievement (Melekoglu, 2011; Baker \& Scher, 2002). The research of Toste, Didion, \& Peng-peng (2020) proves the relationship between reading motivation and reading achievement. Related to the motivation to improve reading skills, it is also seen in the research of Schiefele et al., (2012) that the first three items appear to be closely related to reading self-efficacy (namely, the belief that a person can read successfully), while the other five items measure intrinsic motivation to read. (that is, a willingness to read for the sake of reading).

From the research results of Deci (1992) and Yaffe (1989), it is proven that reading motivation can increase if students have selfconfidence resulting from reading activities with practice (action), such as in dramatization (Deci, 1992). Furthermore Palavan (2017) explores the impact of dramatization in education on selfconfidence. He shows that self-confidence levels increase with learning through dramatization.

This study also shows that the drama tization strategy in learning reading is a strategy that combines the interests of cognitive and metacognitive development so that students' desire to improve reading skills grows. McBreen $\&$ Savage (2020) prove that students who receive cognitive reading interventions show improved reading comprehension. Cognitive interventions are implemented in reading learning with the dramatization strategy, including strengthening decoding and vocabulary.

Reading fluency with the ability to decode words (decoding), such as in dramatized reading learning, is an important tool for good reading comprehension (Schwanenflugel et al., 2006; Miller \& Schwanenflugel, 2006; Kuhn \& Stahl, 2003). Efficient decoding skills are very important to form text representations among components in the cognitive domain, decoding skills can influence the process of obtaining different levels of text representation (Kintsch, 2013). Decoding skills are considered to be one of the main contributors to reading comprehension, especially during the first few years of formal schooling (Gottardo \& Mueller, 2009; Zadeh et al., 2012). Albert \& Foil (2003), the results of their research, prove that using drama activities to teach vocabulary can be an effective instructional practice for developing reading comprehension.

Jacob (1976) shows that there is a strong relationship between readers who have high-level reading skills and the mental images that result from dramatization. Students who learn using mental imaging are more successful in monitoring their understanding of reading results (DuPont, 1992). In addition, DuPont (1992) who studies 11-year-old children gets significantly different scores between students who learn to read discourse by participating in drama activities and those who do not.

This study also proves that the dramatization strategy in reading learning can increase reading motivation to be able to interact socially. This is indicated by a fairly high increase in motivation, namely $8.14 \%$. The tendency for high motivation to read for social interaction can be seen from the age of the respondents who are teenagers, between 9 s.d. 15 years. At this age, they begin to develop friendly relationships that are bound by common interests (Selman, 1980). They desire to read more because they want their friendship to be maintained by providing information to each other. They will get satisfaction if they can communicate the knowledge they get from reading. The researchers conclude that teenagers want to do reading activities because reading provides the social function they need. (Goodman \& Goodman, 1979; Stubbs, 1980; and Teale, 1982). 
Attwood (2007) suggests using drama to teach social skills and to train behavior in certain social contexts. Neelands (2002) argues that drama helps children with social challenges develop their ability to approach situations in a more creative and flexible way, and that it provides them with a better understanding of their own and others' behavior.

\section{CONCLUSION}

With regard to the empirical results, it is concluded that the Dramatization Strategy in Reading Learning is effective in increasing students' reading motivation. This strategy is proven to increase reading motivation, either for groups of students who have high-level reading skills or for groups of students who have lowlevel reading skills. Reading motivation

\section{REFERENCES}

Anderson, R. C., Wilson, P. T., \& Fielding, L. G. (1988). Growth in reading and how children spend their time outside of school. Reading Research Quarterly, 23 (3), 285-303.

Albert, S.R., Foil, C.R. (2003) Drama activities that promote and extend your students' vocabulary proficiency. First Published September 1, 2003 Research Article https://doi.org/10.1177/ 10534512030390010301

Attwood, T. (2007) The complete guide to asperger's syndrome. London: Jessica Kingsley Publish ers.

Baker, L., \& Scher, D. (2002). Beginning readers' motivation for reading in relation to parental beliefs and home reading experiences. Reading Psychology, 23, 239-269.

Boudreault, C. (2010) The Benefits of Using Drama in the ESL/ EFL Classroom. The Internet TESL Journal For Teachers of English as a Second Language.

Cain, K., \& Barnes, M. (2017). Reading comprehension: What develops and when? In K. Cain, D. L. Compton, \& R. K. Parrila (Eds.), Theories of Reading Development. John Benjamins.

Cartwright, K. B., Marshall, T. R., \& Wray, E. (2015). A longitudinal study of the role of reading motivation in primary students' reading comprehension: Implications for a less simple view of reading. Reading Psychology, 37 (1), 5591. https://doi.org/10.1080/02702711.2014.99 1481 increasing the highest is the desire to improve reading skills and the desire to be able to interact socially.

Based on these conclusions, the drama tization strategy is recommended to be implemented by teachers in junior high schools or at Madrasah Tsanawiyah. To be able to carry out the dramatization strategy properly, teachers need to be trained to become proficient in utilizing the learning steps. These steps include (1) developing decoding knowledge; (2) developing vocabulary knowledge; (3) syntactic knowledge development; and (4) discourse knowledge development. These stages are carried out through warm-up activities, games, acting, tableau, simulation, jokes, group games, and interviews. In addition, teachers need to be mentally prepared in implementing this dramatization strategy.

Deci, E.L. (1992). "The Relation of Interest to the Motivation of Behaviour: A Self Determination Theory Perspective", at A. Renninger, S. Hidi, \& A. Krapp (Eds). The Role of Interest in Learning and Development, 43-70. Hillsdale, NY: Lawrence Erlbawn.

De Naeghel, J., Van Keer, H., Vansteenkiste, M., \& Rosseel, Y. (2012). The relation between elementary students' recreational and academic reading motivation, reading frequency, engagement, and comprehension: A self-determination theory perspective. Journal of Educational Psychology, 104 (4), 1006-1021. https://doi. org/10.1037/a0027800

Dieker, L.A \& Little, M. (2005). Secondary reading: Not just for reading teachers anymore. Intervention in clinic. First Published May 1, 2005 Research Article https://doi.org/ 10.1177/ 10534512050400050401

DuPont, S. (1992). The Effectiveness of Creative Drama as an Instructional Strategy to Enhance The Reading Comprehension Skill of FifthGrade Remedial Readers. Reading Research and Instruction. 3L (3), 41-52.

Fraenkel, J.R., Wallen, N.E., \& Hyun, H. (2012) How to Design and Evaluate Research in Education. Boston: McGraw-Hill Education

Goodman, K.S, \& Goodman, Y.M. (1979). Learning to Read is National, in L.B. Resnick \& P.A. Weaver (Eds). Theory and Practice of Early Reading- (1), 137-154. Hillsdale, NY: Larwence Erlbaum Associates. 
Gottardo, A., \& Mueller, J. (2009). Are first-and second-language factors related in predicting second-language reading comprehension? A study of Spanish-speaking children acquiring English as a second language from first to second grade. Journal of Educational Psychology, 101 (2), 330-344. https:// doi.org/10.10 $37 / \mathrm{a} 0014320$

Gottfried, A. W., Schlackman, J., Gottfried, A. E., \& Boutin-Martinez, A. S. (2015). Parental provision of early literacy environment as related to reading and educational outcomes across the academic lifespan. Parenting, 15, 24-38. doi: 10.1080/15295192.2015.992736

Hermida, J. (2009). The importance of teaching academic reading skills in first-year university courses. The International Journal of Research and Review. 3, 20-23

Kintsch, W. (2013). Revisiting the constructionIntegration model of text comprehension and its implications for instruction. In D. E. Alvermann, N. J. Unrau, \& R. B. Ruddell (Eds.), Theoretical Models and Processes of Reading (6th ed., pp. 807-839). International Reading Association.

Jacob, S.H. (1976). Contexts and images in reading. Reading World. 15, 167-175

Kuhn, M. R., \& Stahl, S. A. (2003). Fluency: A review of developmental and remedial practices. Journal of Educational Psychology, 95, 321.

Locher, F.M., Becker, S., Pfost, M (2019). The Relation Between Students' Intrinsic Reading Motivation and Book Reading in Recreational and School Contexts. AERA Open April-June 2019, Vol. 5, No. 2, pp. 1-14 DOI: 10.1177/2 33285841985204https://doi.org/10.1177/2332 85841985204

McBreen, M., \& Savage, R., (2020). The impact of a cognitive and motivational reading intervention on the reading achievement and motivation of students at-risk for reading difficulties. Learning Disability Quarterly. https://doi. org/10.1177/0731948720958128

McGeown, S. P., Osborne, C., Warhurst, A., Norgate, R., \& Duncan, L. G. (2016). Understanding children's reading activities: Reading motivation, skill and child characteristics as predictors. Journal of Research in Reading, 39 (1), 109-125. doi:10.1111/1467-9817.12060

McMaster (1998). Doing literature: using drama to build literacy. In The Reading Teacher $A$ Journal of The International Reading Association. 51,574-584

Melekoglu, M.A. (2011). Impact of motivation to read on reading gains for struggling readers with and without learning disabilities. Learning Disa- bility Quarterly, https://doi.org/10.1177/07319 48711421761

Miller, J., \& Schwanenflugel, P. J. (2006). Prosody of syntactically complex sentences in the oral reading of young children. Journal of Educational Psychology, 98, 839-853.

Mol, S. E., \& Bus, A. G. (2011). To read or not to read: A metaanalysis of print exposure from infancy to early adulthood. Psychological Bulletin, 137, 267-296. doi:10.1037/a0021890

Morgan, L. P., \& Fuchs, D. (2007). Is there a bidirectional relationship between children's reading skills and reading motivation? Council for Exceptional Children, 73, 165-183. doi:10. 1177/001440290707300203

Neelands, J. (2002). Making sense of drama. A Guide to Classroom Practice. UK: Heinemann Educational Books.

Palavan, Ö. (2017). Impact of Drama Education on The Self-Confidence and Problem-Solving Skills of students of Primary School Education. Kastamonu Education Journal, 25 (1).

Quirk, M., Schwanenflugel, P.J, \& Webb, M (2009). A short-term longitudinal study of the relationship between motivation to read and reading fluency skill in second grade. Journal of Literacy Research, 41:196-227, 2009

Schiefele, U. (2011). Interest, learning, and motivation. Educational Psychologist, 26 (3-4), 299323. doi:10.1080/00461520.1991.9653136

Schiefele, U., Schaffner, E., Möller, J., Wigfield, A. (2012). Dimensions of reading motivation and their relation to reading behavior and competence. Reading Research Quarterly, 47(4), 427-463. doi:10.1002/rrq.030

Schwanenflugel, P. J., Meisinger, E. B., Wisenbaker, J. M., Kuhn, M. R., Strauss, G. P., \& Morris, R. D. (2006). Becoming a fluent and automatic reader in the early elementary school years. Reading Research Quarterly, 41, 496522.

Selman, R.L. (1980). The growth of interpersonal understanding: Developmental and clinical analyses. London and New York: Academic Press.

Skaalvik, E. (1997). Self-enhancing and self-defeating ego orientation: relations with task and avoidance orientation, achievement, self perceptions, and anxiety. Journal of educational Psychology. 85. 571-581.

Smith, J. L., \& Herring, J. D. (1993). Using drama in the classroom. Reading Horizons, 33 (5), $418-426$.

Snow, C., (2002). Reading for understanding: Toward R\&D program in reading comprehension. Santa Monica: Rand. 
Stubbs, H (1980). Language and literacy: The sociolinguistics of reading and writing. London: Routledge \& Kegan Paul.

Teale, W.H. (1982) Toward a theory of how children learn to read and write naturally. Language Arts 59, 555-570.

Taylor, M. (2013). Reading for pleasure in Britain: Trends, patterns, and associations. Oxford, UK: University of Oxford.

Toste, J.R., Didion, L., \& Peng-peng. (2020). A metaanalytic review of the relations between moti- vation and reading achievement for $\mathrm{K}-12$ students. https://doi.org/10.3102/00346543209 19352

Yaffe, S.H. (1989). Drama as a teaching tool. Educational Leadership. 46, 29-32.

Zadeh, Z.Y., Farnia, F., \& Geva, E. (2012). Toward modeling reading comprehension and reading fluency in English language learners. Reading and Writing, 25 (1), 163-187. https://doi.org/ 10.1007/s11145-010-9252-0. 